
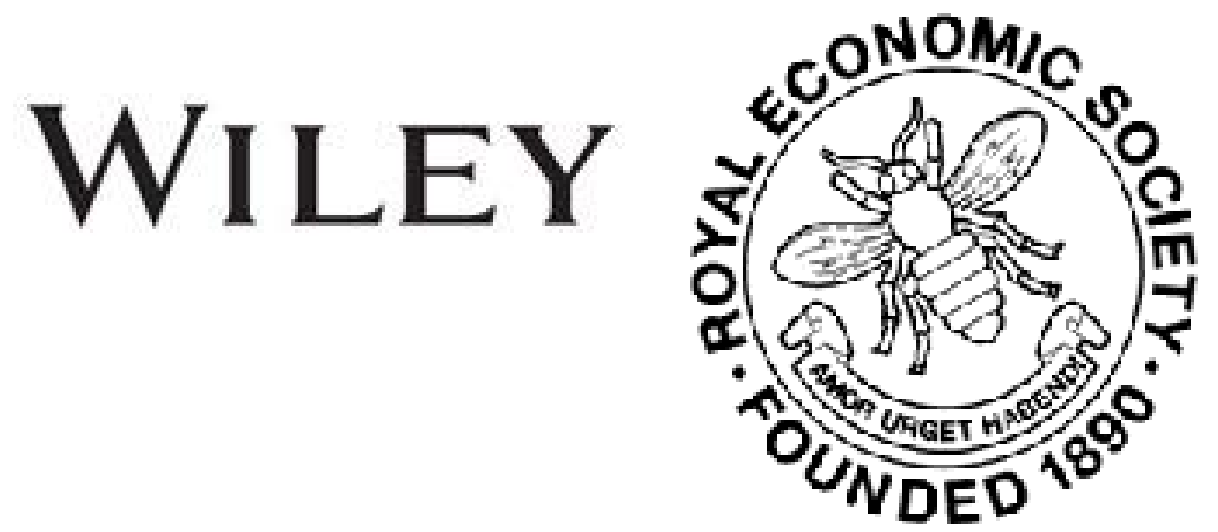

\title{
Review
}

Author(s): C. F. Bickerdike

Review by: C. F. Bickerdike

Source: The Economic Journal, Vol. 24, No. 95 (Sep., 1914), pp. 427-429

Published by: Wiley on behalf of the Royal Economic Society

Stable URL: http://www.jstor.org/stable/2222008

Accessed: 22-05-2016 10:11 UTC

Your use of the JSTOR archive indicates your acceptance of the Terms \& Conditions of Use, available at

http://about.jstor.org/terms

JSTOR is a not-for-profit service that helps scholars, researchers, and students discover, use, and build upon a wide range of content in a trusted digital archive. We use information technology and tools to increase productivity and facilitate new forms of scholarship. For more information about JSTOR, please contact support@jstor.org.

Wiley, Royal Economic Society are collaborating with JSTOR to digitize, preserve and extend access to The Economic Journal 
assist in making Norway, at some future time, a manufacturing country. This, however, is only a very distant possibility, so it is questionable whether the Norwegians of the present day ought on the whole to make any such sacrifice."

Henry W. Macrosty

Economic Notes on English Agricultural Wages. By R. Lennard. (London: Macmillan. 1914. Pp. 154.)

THE author, though anxious to avoid a merely inconclusive result, is fully alive to the complexities of the problem of State regulation of agricultural wages. Within the limit of a small book he contrives to deal with many questions in a very painstaking and impartial spirit. The faults, indeed, seem rather on the side of over-elaboration rather than the reverse. The clearness of the reasoning is rather blurred by the author's anxiety to omit none of the many "possibilities," and this might lead a casual reader to think that the conclusions reached are much less definite than a careful study of the book would show them to be.

The author is definitely in favour of compulsory minimum wages for agriculture, and he points out various reasons for thinking that this policy would neither cause serious unemployment nor lead to any considerable reduction in the numbers employed in agriculture, though it cannot be said that the latter conclusion is reached very decisively.

The reasoning is not specially novel, but the book serves well in bringing together most of what can be said a priori on the subject. There is purposely no labouring of the point that wages are in many districts miserably low, because, as the author says in his preface, "a demonstration of the possibility of improvement is a sufficient reason for action without the sentimental appeal provided by a tale of horror." There is, however, a review of the data as to wages, and some interesting novel statistics of heights and weights of boys aged twelve in rural schools in a number of counties with relatively high wages, and a number with relatively low wages (pp. 83 and 84). The figures show, curiously enough, that the low-wage counties seem to have slightly heavier children than the high-wage counties. Oxfordshire heads the list with an average weight of 76 lbs. (based on 489 measurements), and Derbyshire is lowest with an average of $71 \cdot 3 \mathrm{lbs}$. (3,540 measurements). The author rightly considers, however, that these figures do not refute the generally accepted view that where wages are low the worker is apt to be inefficient through 
lack of adequate nourishment, and that a rise in wages may well be expected to lead to improved efficiency.

The author's theoretical argument that agricultural labour is "cheap" in the sense that "the dearest labour in agriculture is cheaper to the employer than the dearest labour in other trades" seems open to criticism. Let it be granted that agricultural labourers are in a weak position as bargainers, through inability to combine, through the fact that the demand for their services does not grow as rapidly as the natural increase in the supply, and through the hindrances to free mobility into other trades. It is still not by any means clear that they would not be employed up to the point at which the marginal labourer is just worth, to the farmer, the wage he is paid. If it were the case that numbers increased to such an extent that wages were being continually lowered, one might argue that the farmer's tendency to employ them up to the marginal point would lag behind the fall in wages. But the fact is that wages have risen considerably, showing that, in spite of "immobility," there must have been a "pull" from the outside labour market, as well as a push from inside the agricultural group. The farmer's marginal men must have been pulled away from time to time, for how otherwise can we account for the raising of wages? It seems unlikely, therefore, that there is any specially wide gap between the wages paid and the worth to the farmer of his marginal labour.

The author considers, however, that even if there is no specially wide gap of this kind, it is not very probable that a judicious increase of wages would seriously curtail employment in agriculture in the actual circumstances. In this connection it would have been interesting, however, if comparison could be made between the numbers of men employed on farms in those parts of England and Scotland in which wages are high, but in which the type of farming is fairly comparable with the type of farming in the lowwage counties, and the numbers employed in the latter. It is no use comparing the numbers employed over large areas, as is sometimes done, when the high-wage area is predominantly grassfarming. It may be conceded that increased wages, accompanied by increased efficiency, will not, in the circumstances of to-day, lead to further laying down of land to grass. One would like to know, however, whether more efficient and more highly paid labour in Oxfordshire and Cambridgeshire would enable farmers to maintain, or even to improve on, the productiveness of the farms, whilst employing distinctly fewer men, and the best indica- 
tion would seem to be a comparison of numbers employed at the present day on good arable or mainly arable farms in Scotland and in the low-wage counties respectively, omitting, however, the small areas of very exceptional high-farming. It is to be hoped that the author will contrive to supplement his careful analytical study by some such comparison of facts as this.

There is another point which is touched upon briefly, but which seems deserving of more attention-the influence of the rating system. Given that a certain sum of money has to be raised locally, how far is it the case, if at all, that the raising of that sum by means of a rate on the annual value of immovable property gives a bias in the direction of keeping land as rough pasture, rather than ploughing it up or otherwise improving it? It seems probable that our system of raising local revenue may operate strongly in this direction, but it should be possible to show this by means of figures, if they could be obtained, relating to estates in which changes, one way or the other, have been made. This, it is suggested, is another direction in which more concrete investigation is possible. These are only a few of the points of interest touched upon in this book which may be unreservedly recommended to those who are interested in this very live subject.

C. F. BICKERDIKE

\section{An Agricultural Faggot: A Collection of Papers on Agricultural}

Subjects. By R. H. Rew, C.B. (London: P. S. King. 1914. Pp. 183. Price 5s.)

In this volume Mr Rew has collected ten papers, written at various times between 1888 and 1913. Thus a quarter of a century elapsed between the date of the earliest and latest paper. The first half of the period was one of great depression in farming, the second was brightened by a slow convalescence. Five of the ten chapters, I., II., IV., VIII., and X, deal with farming and farm labour, and the other five mainly with the distribution of farm produce. The sticks would have been placed more conveniently in the faggot if this grouping had been followed, especially in view of the fact that the latest of the papers in the second group was written fourteen, and the earliest twenty-five, years before the book was published.

It appears from the introduction that the papers have been printed almost exactly as they were originally written; they have only been "slightly trimmed to lie more conveniently in the faggot." This method of publication has certain disadvantages. 